\title{
供給電力の不確実性を考慮したIPPの導入評価
}

\author{
学生員杉 原英 治 (北海道大学) \\ 正員北裕幸 (北海道大学) \\ 正員西 谷 健一 (北海道工大) \\ 正員長 谷川淳 (北海道大学)
}

\section{An evaluation of the influence caused by the introduction of IPP considering uncertainty of supply capability}

\begin{abstract}
Hideharu Sugihara, Student Member, Hiroyuki Kita , Member (Hokkaido University), Ken-ichi Nishiya , Member (Hokkaido Institute of Technology), Jun Hasegawa, Member (Hokkaido University)
\end{abstract}

\begin{abstract}
Recently, the utility has been able to purchase the electric energy supplied from the Independent Power Producers (IPP) by a de-regulation in the electric industry. This paper evaluates the influence of IPP's uncertainty on utility and/or customer. In general, the production cost of energy supplied from IPPs is lower than that of a utility, however, the IPP's energy has more uncertainty compared with the utility's energy. This paper analyzes the effects caused by IPPs from the following three points: i) By modeling a process of determining purchased power price as a negotiation model, the authors evaluate the influence of its uncertainty on a potentiality to introduce IPPs through variation of the purchased price. ii) The authors evaluate a difference of power systern reliability between a system under the de-regulated environment with IPPs and a conventional system without IPPs. It is assumed that the system reliability is determined by minimizing of the sum of supply cost and outage cost. iii) Finally, the authors evaluate that how the customer's various requirement about the reliability influences the introduced amount of IPPs.
\end{abstract}

キーワード：電カシステム、独立采発電事業者（IPP）、買取洒格、不確実性、ゲ一ム理論

\section{1.はじめに}

電気事業に関する規制緩和が世界的な潮流となる中で, 我が国に抢いても1995年に卸売り発電事業の自由化を主た る内容とした電気事業法の改正が行われたい。こ机を受 け，多くの電気事業者が新規電源の購入に関して入札を奏 施したが，乙心結果，平均競争摔が 4 倍強となるなど、独 立系発電事業者（Independent Power Producer：以下IPPと呼 ぶ）の潜在能力の高さがうかがれれるものとなった。今後 も，IPP䒯入量は確実に增加していくと考えられて拉り, こうした非電気事業者を含む新しい電力システムの特性に

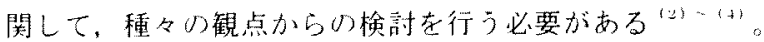

ところで，発電市場八参人してくるIPPは，鉄鋼，石油 化学などの分野が中心となるものと考えられるが，二れら の産業では，熱併給や遊休インフラの利用などにより，一 般に電気事業者より低コストで発電できるという特徵があ る が課されているのに対し，IPPには人柇条件を除き直接的 な制約はなく，自社の利益老最優先し行動和るという側面
も持っている。促って，IPP心供給電力は，低コストでは あるもの心，潜在的にある程度心不確実性が存在拝るとし てモデル化寸るのが実際的と考えられる。今後, IPPの導 入を樍極的に推進し，更なる供給コス卜の低減を图ってい くためには，IPPの持つ不確実性が，電力システムの運用 ・計画や需要家いのサービスなどにどのような影響を与え るのかを詳細に評価することが重要と考えられる。

これまで，IPP供給電力の不確实性を扱った研究として は，主以文献 $(7)(8)$ が举げられる。文献（7)では，ある 一定の発電設備量妾有寸る非電気事業者が参入した場合心 系統内各母線に拄ける供給信頼度の変化老評価しているが， 参人のための買い取り洒格抢上び電父事業者の設備量をも 含めた矛統全体のコストについては検討されていない。ま た文献 (8)では，長期的な観点から、IPP と電気事業者の 将来の発電コストに不確実性が存在するすもとしてモデル 化しているものの、一方の解析を行うときには他方の不確 実性在無視しているため、ここでいう交涉成立条件は、 IPP 上電気事策者間の交涉過程に打ける局所的平衡点を意 
味することになる。また，IPP供給電力の不確実性は，電 気事業者八影響するだけでなく，系統全体の信頼度や一般 需要家への供榆サービスにも大きな影響を与えると考えら れる。

本論文では，IPPを含む新しい電力システムを，IPP，電 気事業者、一般需要家からなるグローバルな市場モデルと して考慮し、各参加者のコストと信賴性に与える影響を具 体的に評価することを目的上する。ただし，全ての影響を 同時にモデル化することは容易ではなく，また，本質的な 相互関係老評洒しつららくする可能性もあるため，いくつか の側面に着目したモデル化に対して解析を行っている。ま ず第 2 章では，単一IPPと電気事業者間における買い取り 価格決定過程在モデル化し，IPPの不確実性が電気事業者 との交涉成立条件に与える影響索評価する。次に第 3 章で は，一般需要家も含めた電力システムにおいて，IPPの不 確実性が需要家の信頼度に対して与える影響を、また第 4 章では，逆に需要家の信頼度に対する多様な要求が，IPP の参入可能性に与える影響を評価する。二れらの評価手法 をモデル系統に適用した結果，不確実性を考慮したIPPの 導入に関するいくつかの重要な知見が得られている。

\section{2. 買い取り交涉に基づくIPPの導入可能性 評価}

一般に電力市場に捛いても，他の財货やサービスの市場 と同様に、IPP と電気事栄者の電力売買を交涉の概念に基 ついて関倸づけることができる(い)。すかわち，自己の利 益を考慮して，IPPは『以上の洒格で売りたいりという 買い取り価格の最低ライン( P四们を要求し，電気事業者は 『以下の洒格で買いたい」というその最高ライン $\left(P_{\max }\right)$

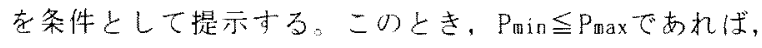
闻者の要求を同時汇満足寸る買い取り洒格が存在すること になるため，その間の適当な洒格で交涉が成立することが 期待できる。本論文では，P $\min \leqq P \leqq P \max の$ 螌囲を，交涉が 成立し得る価格領域上言う意味で交涉成立領域と㭔心。本 章では，IPP川持つ不確害性が，交涉成立領域にどの上う な影響を与えるかを明らかにし，IPPの電力系統内人の導 入可能性について検討寸る。

〈2・1〉IPP尖給電力の不確実性のモデル化一般に， IPP供給電力心不確害性は，長期的な不確赛性と短期的な 不確実性とに大別することができる。長期的な不確実性上 は，十数年にわたる契約期間において，将来心燃料価格， 懐境規制などの変化に上るIPP供給力心脱落の可能性を意 味する。電気事業全体の観点から見ると，電源の建設には 長いリードタイムを要することから，IPPの供給力は長期 的に確保されるものでなければならない。一方，短期的な 不確実性とは，対象期閒をある期間(例えば一年)に限定し た場合のIPP 出力变動意味寸る。この出力変動は, IPP 発電機の故障に起因主万毛の心他に，IPP自身は売電事業 以外の主たる企業活動老行って抢り，自社の不確定な需要
八の電力供給を優先しようとず石行動によって生ずること が考えられる。本諭文では，主に，自社需要い心優先供給 に基つくく短期的な不確寒性に着目抽ることし，IPP心需 給関係を图1のようにモデル化执るこの图に㧍いて， IPP設備量 $\mathrm{A}$ 孝固定量として与えるものとすれ枯，壳電契 約電力は図中の变数Wに基づいて決定される。IPPは契約 電力よりも確率的に変動する自社需要一门供給を優先する ため, 変数Wは，同時にIPP供給電力の不確実性の度合い をも表すことになる。すなわち，Wが大きくなれば契約電 力は滅少するものの，変動の少ない良質な電力が供給され ることになる。

ところで，IPPが自社需要の確率的性質を完全に既知で あるならば，自社需要八の供給を優先しても電気事業者の 要求する信頼度を満たすよう契約電力を決定できるため, 上記のモデル化は妥当と言える。しかし，自社需要の確率 的性質に誤差が含まれる一般の場合には，運用時に電気事 業者の要求する信頼度制約を超えない上う，自社需要を抑 制することも十分に考えられる。著者らは、このようなケ 一スについても考慮する必要があると考えているが，本論 文では簡単のため，自社需要の確率的性質が既知であるも のとして解析している。また、IPPおうよび電気事業者とも 1 時間帯の確率モデルを考えるが，より長期間のモデルに 対しても容易に拡張することができる。

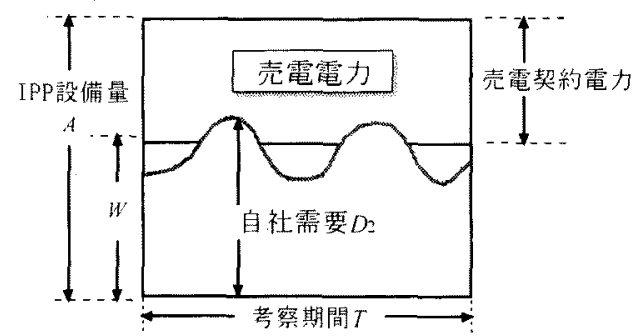

[闵 1 IPPO需給概念闵]

Fig.] Concept of IPP's operation.

〈2・2〉IPPの需給モデル交涉成立時におうけるIPPの総 コストの期待值 $C_{2} は$ 、図 1 の需給概念図に基づいて次式 ひように計算することができる。

$$
\begin{aligned}
C_{2}(W)= & \text { 固定費 }+ \text { 可変費(フル出力時) } \\
& + \text { 可変費(出力余裕時)-売電忦上る収入 } \\
= & A C_{f 2}+T A C_{1 \cdot 2} \int_{H}^{\infty} f\left(D_{2}\right) d D_{2} \\
& +T C_{12} \int_{0}^{H} f\left(D_{2}\right) d D_{2}\left(A-W+\frac{\int_{0}^{H} D_{2} f\left(D_{2}\right) d D_{2}}{\int_{0}^{H \prime} f\left(D_{2}\right) d D_{2}}\right) \\
& -T P_{2}\left(A-W-\int_{W}^{\infty}\left(D_{2}-W\right) f\left(D_{2}\right) d D_{2}\right)
\end{aligned}
$$

こニで、A：1PP時の設備量、C $C 2, C v 2$ : 自家発の固 定費及び可変費、 $D 2$ ：自社需要、 $f(D 2)$ ：自社需要 確率密度関数、P2：電気事業者心買取侣格 
一方，交涉が決裂した場合には，大口需要家は設備量を 維小できるものと五る。その具体例として，我が国の卸売 電力入札制度が举げられる。すな⿰ち, 固定費も含めた買 い取り価格で売電できることが決定した後に，その大口需 要家はIPPとして売電するための設備投資を行うというケ 一スである。従って, 交涉決裂時には自家発と電気事業者 からの買電との両方で自社需要を賄う必要があり, その際 の総コストの期待值は以下のように表される。

$$
\begin{aligned}
& C_{2}^{m}= \text { 固定費+可変費+電気事業者からの買電コス卜 } \\
&= A_{1} C_{f 2}+T C_{l \cdot 2}\left(\int_{0}^{A_{1}} D_{2} f\left(D_{2}\right) d D_{2}+A_{1} \int_{A_{1}}^{\infty} f\left(D_{2}\right) d D_{2}\right) \\
&+P_{1} T \int_{A_{1}}^{\infty}\left(D_{2}-A_{1}\right) f\left(D_{2}\right) d D_{2} \\
& \text { こニで、 } A_{1} \text { : 交渉基隻点の設備量、 } P_{1} \text { : 電気料金 }
\end{aligned}
$$

ただし，設備量Aは，与えられた電気料金P基に，

式を最小化することにより決定する。

$\langle 2 \cdot 3\rangle$ 電気事業者の需給モデル 電気事業者の需給モ デルを図 2 に示す。ここでは，IPPの不確実性が与える影 響老明確にするため、電気事業者によって供給される一般 需要家の負荷については，そ心確率的な变動を無視する。 従って，交渉成立時の電気事業者のコストCり、および交 涉決裂時のコストCり"次式のように表すことができる。 ただし，IPP内需要の不確実性による電気事業者の予備力 $\alpha$ 及び交渉決裂時に大口需要家の買電により生じる設備量 の増分 $\beta$ は，何れもLOLP基準（0.1\%）に基づいて決定す 万。

$$
\begin{aligned}
C_{U}= & \text { 固定費 }(\text { 平常用電源分, 繁急用電源分 }) \\
& + \text { 可変費 }(\text { 平常用電源分, 緊急用電源分 }) \\
& + \text { 買電による支出 } \\
= & B C_{f}+\alpha C_{f}^{p}+B T C_{1}+T C_{l}^{p} \int_{W}^{W+\alpha}\left(D_{2}-W\right) f\left(D_{2}\right) d D_{2} \\
& +T P_{2}\left(A-W-\int_{W}^{\infty}\left(D_{2}-W\right) f\left(D_{2}\right) d D_{2}\right)
\end{aligned}
$$

$$
\begin{aligned}
C_{U}^{m}= & =\text { 固定費 }(\text { 一般需要分, 大口需要家の買電分 }) \\
& + \text { 可変費 }(\text { 一般需要分, 大口需要家 } 0 \text { 買電分 }) \\
& =C_{f}\left(D_{1}+\beta\right) \\
& +T C_{V}\left(D_{1}+\int_{A_{1}}^{A_{1}+\beta}\left(D_{2}-A_{1}\right) f\left(D_{2}\right) d D_{2}\right)
\end{aligned}
$$

ここで、B: 電気事業者の設備量、 $D 1:$ 一般需要、 $C f f_{2} v$ : 平常用電源の固定費及び可変費、 $\mathrm{C}^{\mathrm{n}}, C{ }^{\mathrm{n}}$ : 緊急用電源の固定費及び可変費

なお、交涉成立時に、特に緊急用電源を設けているのは、 IPP導入により、電気事業者が供給しなければならない負 荷の変動が大きくなり、より即応性の高い電源を準備して おく必要があるとの考えに基づいている。
ところで，前節で述べたように，交渉決裂時には，IPP 心設備量 $A$ は，電気事業者が提示吉る電気料金Pによって 決定される。一方，Pは、いわゆる原価主義制約に基づき (4)式を用いて算出されるとすると, 逆にA1の関数として 与えられる。従って，P 本論文では，(2)式と(4)式龙反復す歹ことで両者の值を求 めている。

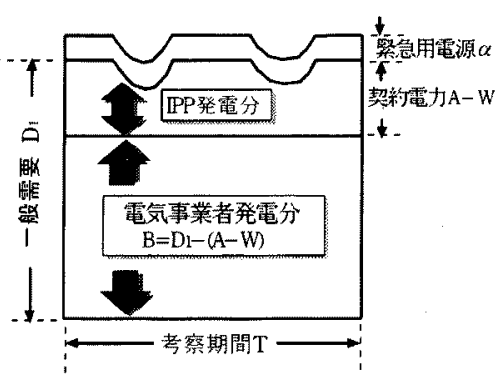

図 2 電気事業者の需給概念図

Fig.2 Concept of utility's operation.

\section{〈2・4〉ダーム理論に基づく交涉成立領域の決定}

(1) 交渉成立領域IPPにとつて心交渉成立条件は, 交渉成立時のコストが決裂時よりも小さくなればよいので 次式のように表される。

$$
C_{2}^{m} \geq C_{2}\left(P_{2}, W\right)
$$

ここで、上式の等号が成立するP 格はIPPにおける交渉成立の限界コス卜となる。また，電 気事業者にとっての交涉成立条件も同様に求めることがで きるが，電気事業者は交涉決裂時に大口需要の一部をも供 給しなければならないため，単純にコストの大小比較で意 志決定することができない。そこで，IPP参入に伴い一般 需要家への電気料金を上昇させないという(6)式の条件,

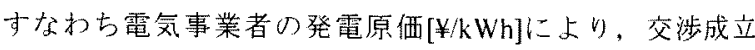
への意志決定を行うものとする。

$$
\frac{C_{U}^{m}}{D_{1} T+T \int_{A_{1}}^{A_{1}+\beta}\left(D_{2}-A_{1}\right) f\left(D_{2}\right) d D_{2}} \geq \frac{C_{U}\left(W_{,}, P_{2}\right)}{D_{\mathbf{1}} T}
$$

上記と同様に(6)式の等号が成立ずる時の買取価格 $P_{z}^{\prime \prime}$ は、 電気事業者における限界コストとなる。以上により，交涉 領域は，(5)(6)式における買い取り伍格を用いて以下のよ うに表すことができる。

$$
P_{2}^{I P P} \leq P_{2} \leq P_{2}^{U}
$$

(2)Nash交涉解およびコストメリット和＼cjkstart交涉成立に 伴うコストメリット和 $T M$ を求めると，買い取り価格 $P 2 k$ 関する項は相殺され，次式のようにWのみの関数になる。

$$
T M(W)=\left\{C_{2}^{m}-C_{2}\left(P_{2}, W\right)\right\}+\left\{C_{U}^{m}-C_{U}\left(P_{2}, W\right)\right\}
$$


このように、ここでのゲームはコストメリット和の最大化 の钼点から，交涉成立領域内で買い取り価格が一意に決定 されない，い扒ゆる定和ゲームと考えることができる。そ こで、ダーム理論において、論理的な交涉解概念の一つと して考えられており，お互いのメリットの積を最大化する Nash交渉解の概念を適用すると、買い取り価格P2 次式の ように決定することができる。

$$
P_{2}^{\prime \prime}(W)=M_{P_{2}} A X\left\{C_{2}^{m}-C_{2}\left(P_{2}, W\right)\right\}\left\{C_{U}^{m}-C_{U}\left(P_{2}, W\right)\right\}
$$

ここで, 定和ゲームに打けるNash交涉解は, 交涉成立に

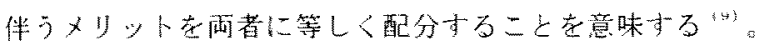
〈2.5〉数值計算例 付表 1,2 に示寸試算データを用 いて行っだ結果在図 $3 ， 4$ 亿示す。ただし，本章では一般 需要確率変数ではなく定数ししてモデル化しているたか, 付表 2 の平均值を用いている。WU增加に従い，IPPの不 確実性は減少するため，交涉領域は高いレベルとなり， Nash交涉解はその中点に位置することがわかる。IPPの不 確実性が隇少すると, 電気事業者は緊急用電源の設備量老 抑制できるため，買い取り価格を高く設定することができ る。一方，IPP側では信頼性の高い電力を供給するた如に, 契䄪電力在抑制する必要が生じるため、より高い買い取り 価格を要求することになる。このように交渉領域に含まれ る心゙き買い取り価格の決定には，IPP 0 不確実性が大きく

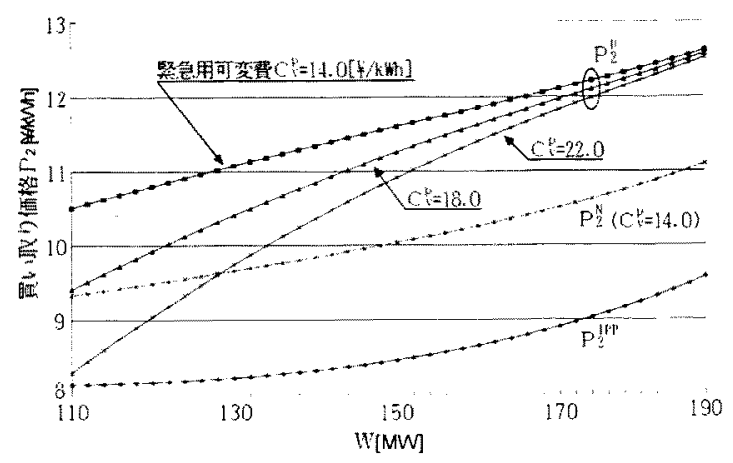

国 3 交涉領域とNash父涉解

Fig.3 Negotiation domain and Nash bargaining solution.

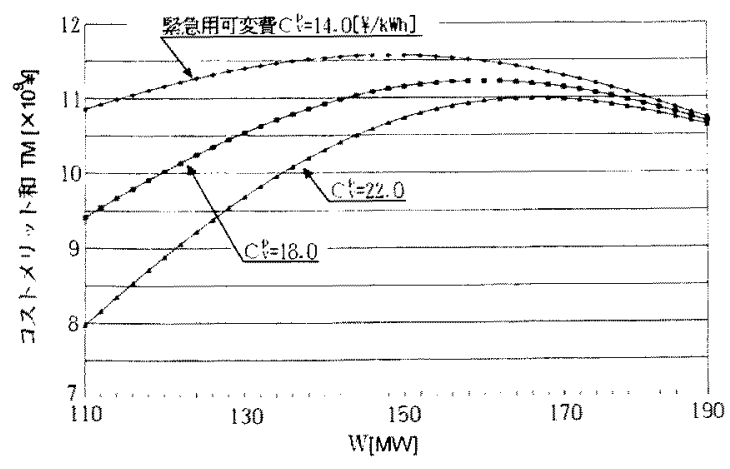

图 4 2xy以和

Fig.4 Summation of Cost merits.
影響することが分かる。また，园 4 からわかるむうに、 ストメリット最大化の钼点から，壳買電力の理論的な信頼 性（不確寒性）の度合い在決定求ることができる。

ところで、IPP供給電力心不確寒性が增加した場合、電 気事業者はその運用時に、運転予備力增加させるなどの 二次的なコス卜上景が生じると考えられる。そこで, 等価

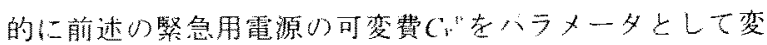
化させ、その影響について評洒寸る。图 3 から、緊急用電 源コストの上昇により交涉領域は狭くなることが分かり、 また図 4のコストメリット和TMの観点からは，そのコス 卜上昇によりTM在最大化求るWW值が大きくなり、IPPの 不確実性老排除するように動くことがすかる。

\section{3、IPP参入が需要家信頼度へ与える影響評価}

前章では，一般需要家への供給信賴度(LOLP)が一定で あるという条件のもとで，IPPと電気事業者のみの交涉モ デルを考えた。その結果，売買される電力の信頼性(不確 実性)は、再者のコストメリットの和が最大(総コストが 最小りとなるうに決定できることを明らかにした。とこ ろで，IPP上電気事業者に加え，一般霜要家老も考慮した 市場モデルに拈いては，売筫電力心信頼性は，同様に3者 の総コストが最小となるよう決定できると考えられる。本 章では，一般需要家のコストとして，供給信頼度に依存す る停電コスト老用いることとし，IPPの参入によって、望 ましい供給信頼度がどのように变化するかについて評価す 30

〈3・1〉サービス価值基淮による供給信賴度の決定 "

IPPの不確赛性が需要家に対して与える影響を評価する ために，図５に示すサービス価值基準の概念を採用する。 これは，(10)式で定義される社会コス卜を最小化すること 以より，望定しい信頼度在決定寸石考之方で，最適性条件

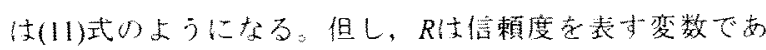
万。

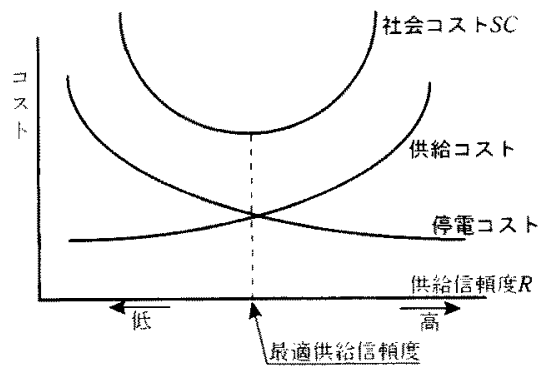

図 5 サービス価値基淮の概念図 Fig.5 Concept of Value of Service.

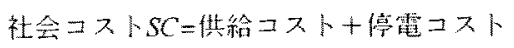

$\frac{\partial(\text { 供給コスト) }}{\partial R}=-\frac{\partial(\text { 停霹コスト) }}{\partial R}$ 
〈3・2〉IPP参入前の電カシステムにおける社会コスト

一般需要家も考虑した书場モデルを考えるため，一般需 要の解荷も確涪変数としてモデル化する。IPP参入前の電 力供給形態としては，2章で述心゙た交涉決裂時を考えれば 上い。従って, 大口需要家り自家発設備量 $A_{1}$ を越える負荷 は，電気事業者から供給されることになり，電気事業者が 担う実際の負荷Z1おび，乙の確率密度関数 $q\left(Z_{1}\right)$ は次の上 うに表さ机るいッ。

$$
\begin{aligned}
Z_{1}= \begin{cases}D_{1}+\left(D_{2}-A_{1}\right) & \left(D_{2}>A_{1}\right) \\
D_{1} & \left(D_{2}<A_{1}\right)\end{cases} \\
q\left(Z_{1}\right)=\int_{0}^{A_{1}} f_{2}\left(Z_{1}, D_{2}\right) d D_{2}
\end{aligned}
$$

但し、 $f\left(D_{1}, D_{2}\right): D_{1}, D_{2}$ の 2 次元正規分布の確率密 度関数

従って, 電気事業者の供給コストCけおよび自家発（大口 需要家) の供給コストCは，次式のように表される。

$$
\begin{aligned}
C_{L^{\prime}}\left(A_{1}, B_{1}\right) & =B_{1} C_{f} \\
& +T C_{V} \cdot\left(\int_{0}^{B_{1}} Z_{1} q\left(Z_{1}\right) d Z_{1}+B_{1} \int_{B_{1}}^{\infty} q\left(Z_{1}\right) d Z_{1}\right)
\end{aligned}
$$

$$
\begin{aligned}
C_{Y}\left(A_{1}\right) & =A_{1} C_{f 2} \\
& +T C_{V 2}\left(\int_{0}^{A_{1}} D_{2} f\left(D_{2}\right) d D_{2}+A_{1} \int_{A_{1}}^{x} f\left(D_{2}\right) d D_{2}\right)
\end{aligned}
$$

また, 一般需要家の停電コストC は不足電力量の期待値 (EUE) と停電単価 $\alpha[¥ / \mathrm{kWh}]$ 積として次式のように表 すものとする。

$$
C_{D}\left(A_{1}, B_{1}\right)=\alpha T \int_{B_{1}}^{\infty}\left(Z_{1}-B_{1}\right) q\left(Z_{1}\right) d Z_{1}
$$

なお，(10)式の社会コストを求好とき，料金に関する項 は相殺されるため，3者のコストは純粋な発電コストによ り構成される。結局，社会コストSCは次式の上うに表さ れ, 大口需要家 自家発設備量 $A$ およひ電気事業者の設備 量 $B 1$ 変量として最小化する。

$$
S C_{1}\left(A_{1}, B_{1}\right)=C_{U}\left(A_{1}, B_{1}\right)+C_{.}\left(A_{1}\right)+C_{D}\left(A_{1}, B_{1}\right)
$$

〈3・3〉IPP参入後の電カシステムにおける社会コスト IPP参入後の電力供給形態としては， 2 章の交涉成立時 の形態によって記述することができる。但し，変数Wを IPPが自律的に決定するゆではなく，社会コス卜を最小化 するための決定変数とする必要がある。電気事業者の供給

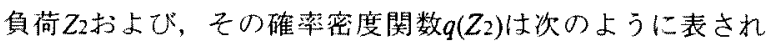
万。

$$
Z_{2}= \begin{cases}D_{1}-\left(A-D_{2}\right) & \left(D_{2}>W\right) \\ D_{1}-(A-W) & \left(D_{2}<W\right)\end{cases}
$$

$$
\begin{aligned}
q\left(Z_{2}\right) & =\int_{0}^{W} f_{2}\left(Z_{2}+A-W, D_{2}\right) d D_{2} \\
& +\int_{W}^{\infty} f_{2}\left(Z_{2}+A-D_{2}, D_{2}\right) d D_{2}
\end{aligned}
$$

上記の変数および電気事業者の設備量B2を用いて, 電気事 業者およびIPPの供給コストC $14, C I P P$, 一般需要家の停電 コストCいは，次式のように表すことができる。なお，IPP 参入前のケースと同様に，料金に関する項は省略する。

$$
\begin{aligned}
C_{U}\left(W, B_{2}\right)= & B_{2} C_{f}+T C_{1} \cdot\left(\int_{0}^{B_{2}} Z_{2} q\left(Z_{2}\right) d Z_{2}\right. \\
& \left.+B_{2} \int_{B_{2}}^{\infty} q\left(Z_{2}\right) d Z_{2}\right) \\
C_{I P P}(W)= & A C_{f 2}+T C_{V 2}\left((A-W) \int_{0}^{W} f\left(D_{2}\right) d D_{2}\right. \\
& \left.+\int_{0}^{W} D_{2} f\left(D_{2}\right) d D_{2}+A \int_{W}^{\infty} f\left(D_{2}\right) d D_{2}\right) \\
C_{D}\left(W, B_{2}\right)= & \alpha T \int_{B_{2}}^{\infty}\left(Z_{2}-B_{2}\right) q\left(Z_{2}\right) d Z_{2}
\end{aligned}
$$

従って、社会コストSC2は次式のようになる。

$$
S C_{2}\left(W, B_{2}\right)=C_{U}\left(W, B_{2}\right)+C_{I P P}(W)+C_{D}\left(W, B_{2}\right)
$$

$\langle 3 \cdot 4\rangle$ 数值計算例 (17)式及び(23)式の最適化計算結 果を表 1 に示す。ただし，付表 $1 ， 2$ に示寸試算データを 用いて，それぞれの決定変数 $A 1$ と $B 1$ 及び $W$ と $B_{2}$ 全数探索 を行い, 社会コストの最小点を算出した。ここで, 需要家 停電単価は700[¥/kWh] と仮定し, 一般需要と大口需要間の 不等時性の影響を評価寸るため，2次元正規分布の相関係 数をバラメータとして用いた。また表 2 は、両需要が無相 関の時のIPP参入前後における信頼度基準值を満たす最小 供給コストを示している。IPP参入前上比心゙参入徭の方が, サービス価值基準に基つく最適供給信頼度は低下する。こ の理由としては，停電コス卜をEUEの線形関数としてモデ ル化しているため, (11)式の限界停電コストはIPP参入の 前後で常に停電単価 $\alpha[¥ / \mathrm{kWh}]$ に等しい。しかし, 表 2 に 示卞結果より供給コストカーブは図60ように変化してい ると考えられ，(11)式の限界コスト均等化条件を満たすよ うに最適な供給信頼度は低下寸ることになる。また，表 1 より大口需要家と一般需要家の負荷の間の相関が大きくな

表 1 最適供給信頼度(EUE)の変化

Table 1 Variation of optimum reliability (EUE).

\begin{tabular}{c|c|c|c|c}
\hline \multirow{2}{*}{$\begin{array}{c}\text { 相関 } \\
\text { 係数 }\end{array}$} & \multicolumn{2}{|c|}{ 最適EUE值[MW] } & EUE $O$ 差 & $\begin{array}{c}\text { 最適W值 } \\
\text { IPP参入娞 }\end{array}$ \\
\hline 0.0 & IPP参入前 & {$[\mathrm{MW}]$} & {$[\mathrm{MW}]$} \\
0.3 & 0.6380 & 0.6277 & 0.0103 & 180 \\
0.6 & 0.6669 & 0.6331 & 0.0139 & 183 \\
0.9 & 0.6904 & 0.6424 & 0.0245 & 187 \\
\hline
\end{tabular}


るにつれて、変数Wの值は大きくなり、さらにIPP導入に 上る供給信頼度心低下分も大きくなることがすかる。

表 2 供給コストカープの変化

Table 2 Variation of supply cost curve

\begin{tabular}{|c|c|c|c|}
\hline \multirow{2}{*}{$\begin{array}{c}\text { 信頼度基櫵值 } \\
\text { EUE[MW] }\end{array}$} & \multicolumn{3}{|c|}{ 最小供絵コスト $[\times 10 ¥]$} \\
\hline & IPP参入前 & IPP参入㣪 & 差 \\
\hline 1.5 & 23712 & 23061 & 651 \\
\hline 1.0 & 23881 & 23232 & 649 \\
\hline 0.5 & 24152 & 23507 & 645 \\
\hline 0.1 & 24701 & 24079 & 626 \\
\hline
\end{tabular}

供給コスト

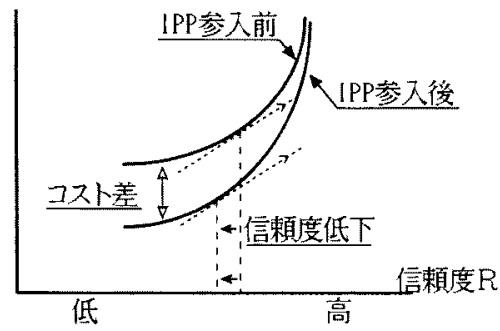

図 6 供給コストカーブ変化の概念図

Fig.6 Concept of supply cost curve variation.

\section{4.需要家信頼度がIPP参入量に与える影響}

前章の解析で, IPP心参入は社会コスト最小化の観点に 基づくと，采統全体心信頼度索西程度低下させる可能性 が苏ることを明らかにした。従って，信頼度を現状のレ心゙ ルに維持ずる必要がある場合には、IPPの参入量は抑制さ れることになる。ところで, 需要家の要求する電力の品質 は、本来多様で支り、コストとの兼权合いに上って決まる 適当な信頼度レベルが各需要家每に存在するものと考えら れる。こうした信頼度いの多样な要求を考慮すると, IPP の参入可能性が大きく広がるものと考えられ，本章では， 同様に社会コスト最小化の観点に基づいて，IPP 参入可 能性落評価寸る。

〈4・1〉IPP参入可能性評価のための大口需要家モデル

IPP心参入可能性を評価するために，图７に示すように 大口需要家が可変費4.0〜 7.9[¥/kWh]まで0.1[¥/kWh]毎に分 布していると抽"口。従って，霓気事業者から提示され た買い取り価格でコストメリットの存在する大口需要家の みがIPP上して電力供給することになる。才なおち, IPPと なるたかの限界の可変費が存在し，二の限界可変費を用い て，大口需要家集合LはIPPとならない集合LaとIPPとなる 集合 $L b$ 分けることができる。限界可変費の值が大きい ほど，多くのIPPに参入心機会があることになり，参入可 能性は高いものとして評価できる。また，大口需要家の設 備量は 2 章上同様に，交涉決裂後（IPPとならない部分） は，設僃量を最適に縮小できるものとする。ここで簡単の
ため，可変費の異なる各大口需要家り自社需要間に打ける

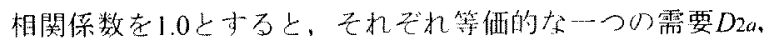
D $2 h$ にまとめるとができ，その確率変数は次式に示す正

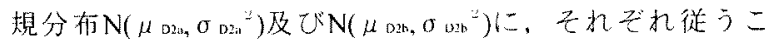
とになる

$$
\left.\begin{array}{l}
\mu_{D_{2 a}}=\sum_{i \in L_{L i}} \mu_{D_{2}}, \sigma_{D_{2 a}}=\sum_{i \in L_{u}} \sigma_{D_{2 l}} \\
\mu_{D_{2 h}}=\sum_{i \in L_{h}} \mu_{D_{2 i}}, \sigma_{D_{2 h}}=\sum_{i \in L_{h}} \sigma_{D_{2 i}}
\end{array}\right\}
$$

さらに、上述の等洒需要に対する等価設備量についても、 次式老用いて求めることができる

$$
A_{T}=\sum_{i \in L_{b}} A_{i} \quad A_{1 T}=\sum_{i \in L_{a}} A_{1 i}
$$

また変数Wについても、現在の日本の入札制度では全ての IPPに対して同一信頼度要求しているこ上考慮し、次 式を用いて等価需要D $2 b$ 対打万変数Wlを定義する。

$$
W_{T}=\sum_{i \in L_{b}} W_{i}
$$

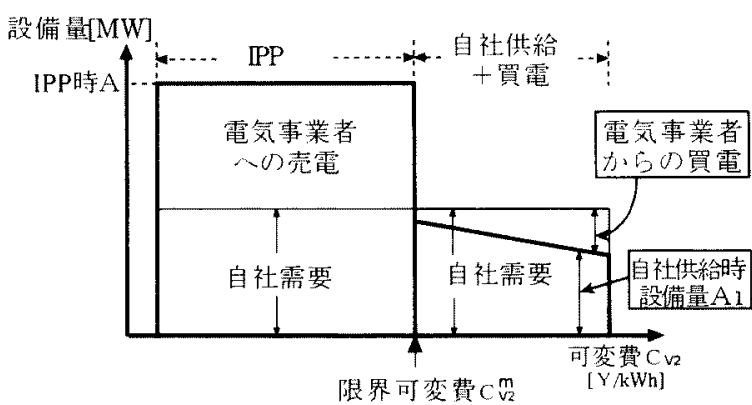

図 7 IPP (大口需要家) 集合のモデル化 Fig.7 Modeling of IPP set.

〈4・2〉買い取り価格を既知とした限界可変費の決定 IPP抢よび大口需要家のコスト関数は，それぞれ(1)(2)式で 表される。従って, 買い取り洒格 $P_{2}[¥ / \mathrm{kWh}$, 電気料金

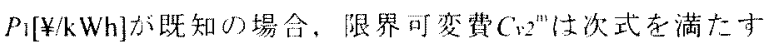
可変類となる。

$$
C_{2}\left(P_{2}, C_{l^{\prime} 2}^{m}\right)=C_{2}^{m}\left(P_{1}, C_{l^{\prime} 2}^{m}\right)
$$

〈4・3〉限界可変費を既知とした買い取り価格の決定 次に，限界可变費怙なおちIPP參入量を既知とした場合心 電気事業者の買い取り洒格の算出について述心゙る。本節で の買い取り価格は，2章の上うに交涉にではなくIPPにと って最もメリットの大きい回避可能原価に基づいて決定さ れるとするるここで，回澼可能原価とはIPPが参入するこ とによる電気事業者側の回避コス卜をIPP供給電力量で割 ることにより算出される。

まず，IPP供給力在考箅せず電器事業者が供給しなけれ 
ばならない負荷 $Y_{1}$ よずその確摔密度関数 $g\left(Y_{1}\right)$ を求める。 この負荷乙老䉓気事業者の汃が供給寸る場合のコスト $C u^{n}$ は(30)式を用いて求めることができる。

$$
\begin{aligned}
Y_{1}= \begin{cases}D_{1}+\left(D_{2 a}-A_{1 T}\right) & \left(D_{2 a}>A_{1 T}\right) \\
D_{1} & \left(D_{2 a}<A_{1 T}\right)\end{cases} \\
g\left(Y_{1}\right)=\int_{A_{1 /}}^{\infty} f_{2}\left(Y_{1}+A_{1 T}-D_{2 a}, D_{2 a}\right) d D_{2 a} \\
\\
+\int_{0}^{A_{1 T}} f_{2}\left(Y_{1}, D_{2 a}\right) d D_{2 a}
\end{aligned}
$$

この負荷Z在電気事業者のみが供給する場合のコストCU" は(30)式を用いて求女ることができる。但し、電気事業者 の設備量Bは、(31)式のLOLP基準值に基づき決定する。

$$
\begin{aligned}
& \begin{aligned}
C_{U}^{n} & =\text { 固定費 }+ \text { 可変費 } \\
& =B C_{f}+T C_{V}\left(\int_{0}^{B} Z g\left(Y_{1}\right) d Y_{1}+B \int_{B}^{\infty} g\left(Y_{1}\right) d Y_{1}\right)
\end{aligned} \\
& \text { LOLP基淮值 }>\int_{B}^{\infty} g\left(Y_{1}\right) d Y_{1}
\end{aligned}
$$

次に，前述の賲荷 $Y_{1}$ をIPP と共に供給する場合の電気事業

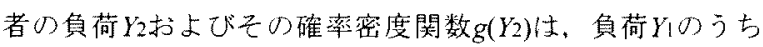
IPPが供給できない部分に相当するるので以下の上うに表す ことができる。

$$
Y_{2}= \begin{cases}D_{1}-\left(A_{T}-W_{T}\right) & \left(D_{2 a}<A_{1 T} \& D_{2 b}<W_{T}\right) \\ D_{1}-\left(A_{T}-D_{2 b}\right) & \left(D_{2 a}<A_{1 T} \& D_{2 b}>W_{T}\right) \\ D_{1}+\left(D_{2 a}-A_{1 T}\right)-\left(A_{T}-W_{T}\right) & \left(D_{2 a}>A_{1 T} \& D_{2 b}<W_{T}\right) \\ D_{1}+\left(D_{2 a}-A_{1 T}\right)-\left(A_{T}-D_{2 b}\right) & \left(D_{2 a}>A_{1 T} \& D_{2 b}>W_{T}\right)\end{cases}
$$

$$
\begin{aligned}
& g\left(Y_{2}\right)= \int_{0}^{W_{T}} \int_{0}^{A_{1 T}} f_{3}\left(Y_{2}+\left(A_{T}-W_{T}\right), D_{2 a}, D_{2 b}\right) d D_{2 a} d D_{2 b} \\
&+\int_{W_{7}}^{\infty} \int_{0}^{A_{1 l}} f_{3}\left(Y_{2}+\left(A_{T}-D_{2 b}\right), D_{2 a}, D_{2 b}\right) d D_{2 a} d D_{2 b} \\
&+\int_{0}^{W_{7}} \int_{A_{1 /}}^{\infty} f_{3}\left(Y_{2}-\left(D_{2 a}-A_{1 T}\right)+\left(A_{T}-W_{T}\right),\right. \\
&\left.D_{2 a}, D_{2 b}\right) d D_{2 a} d D_{2 b} \\
&+\int_{W_{1}}^{\infty} \int_{A_{1 /}}^{\infty} f_{3}\left(Y_{2}-\left(D_{2 a}-A_{1 T}\right)+\left(A_{T}-D_{2 b}\right),\right. \\
&\left.D_{2 a}, D_{2 b}\right) d D_{2 a} d D_{2 b}
\end{aligned}
$$

ここで、 $\left.f\left(D_{1}, D_{2} a, D 2 b\right): D 1, D_{2} a, D_{2} b 0\right) 3$ 次元正規分布 の確率密度関数

従って、IPPからの供給電力が存在する場合の電気事業者 の供給コストCU'は、次式のように求めることができる。

$$
\begin{aligned}
C_{U}^{r} & =\text { 固定費 }+ \text { 可変費 } \\
& =B C_{f}+T C_{1} \cdot\left(\int_{0}^{B} Y_{2} g\left(Y_{2}\right) d Y_{2}+B \int_{B}^{\infty} g\left(Y_{2}\right) d Y_{2}\right)
\end{aligned}
$$

但し、設備量Bは、IPP供給電力を考慮しない場合と同様
に、次式のLOLP基淮值に基づき決定する。

$$
\text { LOLP 基淮值 }>\int_{B}^{\infty} g\left(Y_{2}\right) d Y_{2}
$$

従つて，雪気事業者がIPPに対して提示ずる買い取り佰格 （回避可能原価） $P_{2}$ は，次式を用いて決定寸゙ることができ る。

$$
\begin{aligned}
P_{2}\left(C_{V_{2}}^{m}\right) & =\frac{\mathrm{IPP} \text { 参入に伴うコスト滅少分 }}{\operatorname{IPP} \text { 供給電力量 }} \\
& =\frac{C_{U}^{n}-C_{U}^{r}\left(C_{V 2}^{m}\right)}{T\left(A_{T}-W_{T}-\int_{W_{T}^{\prime}}^{\infty} D_{2 b} f\left(D_{2 b}\right) d D_{2 b}\right)}
\end{aligned}
$$

〈4・4〉IPP参入可能性評価アルゴリズム(13) 図 8 に 提案古万IPP参入可能性評価手法示示。前述 $心\langle 4 \cdot 2\rangle$ 限界 可変費の決定（図 80 (10)）と〈4·3〉買い取り価格の決定 (9) は，相互に影響するため反復計算を行い，収束点を 求めている(3)〜(12))。な㧍，そ心際，電気料金P拉上び 設備量Aについても，原価主義制約に基づき決定されると しているため，〈2・3〉節と同様に反復計算を行っている (4)〜8)，さらに, 需要家の要求する信頼度レベルの変 化を, 需要家停電単価 $[¥ / \mathrm{kWh}]$ 变化としてモデル化し, サービス価值基準を用いて(31)(35)式におう施るLOLP基準值 を決定する（(2)〜15)。才なおち，3章における大口需要 家とIPPが共存する電カシステムを考え, LOLP基準值を変 化させながら，社会コスト最小点に拀けるIPP参入量を決 定する。以上の計算を，停電単価の値を変化させながら実 行し, 停電単価の変化がIPP参入量八与える影響を評価す 万。

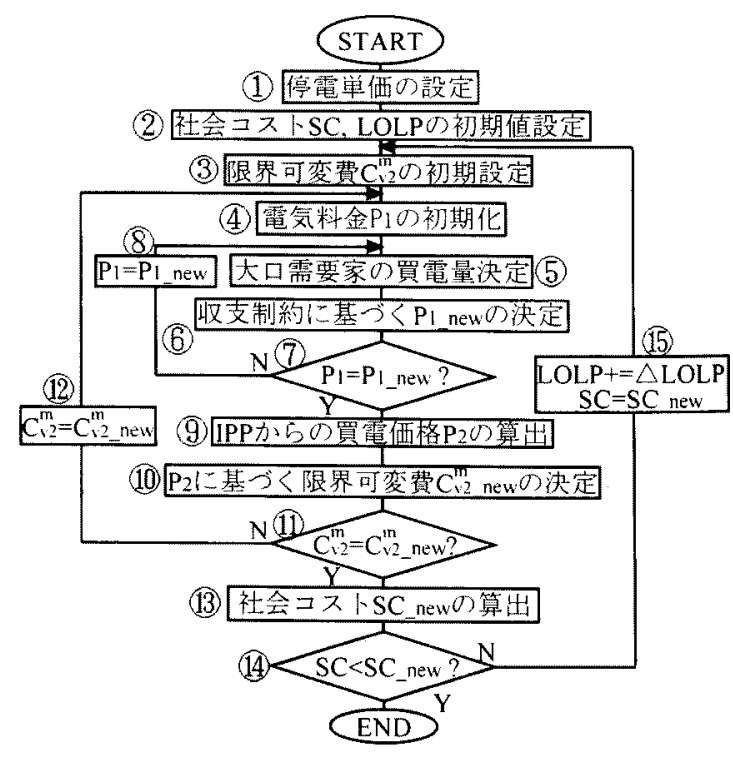

図 8 IPP参入量評洒手頗

Fig. 8 A procedure of IPP to be introduced. 
〈4·5〉数值計算例 付表 $1 、 2$ に示寸試算デー夕を用 いて行つた試算結果を図 9 および表 3 に示す。ただし、大 口需要家集合のデータとして、表 4 に示すデータを用いた。

図 9 上りIPP内自社需要と一般需要が正の相関を有する 場合，需要家停電単価の上昇に従い，IPP参入量が抑制さ れている。つまり,IPP供給電力の不確実性が発電設備自 身の故障に起因する場合、一般需要の変動之は独立に発生 すると考えられるため，停電単研の変化はIPPの参入量八 影響しない。しかし，IPPの不確実性が自社需要八の優先 供給に起因する場合には。両需要閒には少なからず正の相 関が存在すると考えられるため, 停電単価の上昇に上り IPP参人量は抑制されるといえる。また，同一の停電単価 において相関係数が小さくなる上電気事業者は効率的な設 備構成とすることができるため回避可能原価が上昇し， IPPの参入量を促進する効果があることが扐かる。表 3 は、 IPP参入量が変化できる場合の社会コスト最小化に基つく 信頼度レベルであり、表】と同様に相関係数が大きくなる につれ信頼度が低下すること老している。

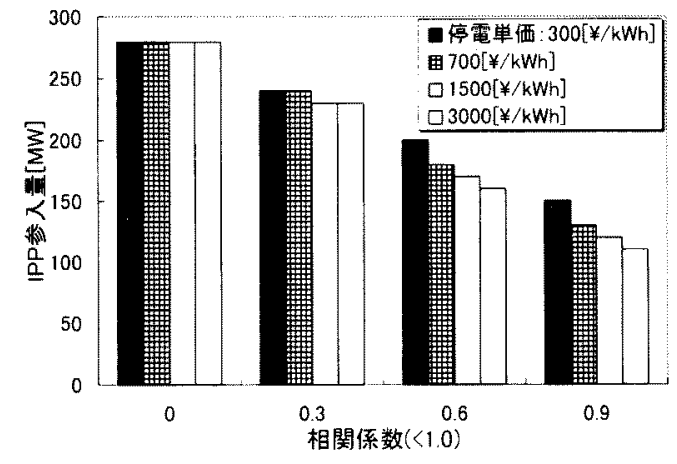

图 9 IPP参入量の変化.

Fig. 9 Change of the amount of IPP to be introduced amount.

表 3 信頼度レベルの变化

Table 3 Change of the reliability level.

\begin{tabular}{|c|c|c|c|c|}
\hline \multirow{2}{*}{$\begin{array}{r}\text { 停電単価 } \\
{[¥ / \mathrm{kWh}]}\end{array}$} & \multicolumn{4}{|c|}{ 不足電力量の期待值[MW] } \\
\hline & $\rho=0.0$ & $\rho=0.3$ & $\rho=0.6$ & $\rho=0.9$ \\
\hline 300 & 1.839 & 1.901 & 1.975 & 2.033 \\
\hline 700 & 0.582 & 0.605 & 0.623 & 0.637 \\
\hline 1500 & 0.276 & 0.284 & 0.297 & 0.304 \\
\hline 3000 & 0.130 & 0.132 & 0.136 & 0.139 \\
\hline
\end{tabular}

表 4 大口需要家集合の試算データ

Table 4 Data for large customer set.

\begin{tabular}{c|l}
\hline \multicolumn{1}{c|}{ 固定費 } & $40000[¥ / \mathrm{kW}]$ \\
可変費 & $4.0 \sim 7.9[¥ / \mathrm{kWh}] \quad(0.1[¥ / \mathrm{kWh}]$ 刻み $)$ \\
設備量 $\mathrm{Ai}$ & $10[\mathrm{MW}]$ \\
自社需要 $\mathrm{D} 2 \mathrm{i}$ & 正規分布 $\mathrm{N}\left(5.1^{2}\right)[\mathrm{MW}]$ \\
変数Wi & $5[\mathrm{MW}]$ \\
\hline
\end{tabular}

\section{5.まとめ}

本諭文では，電気事業者がIPP心供給電力を買い取る制 度において, IPP供給電力の不確実性が与える様々な影響 を，それぞれの適切なモデル化に基づき評価する手法を提 案した。これらの提案手法をモデル系統に適用した結果, 次のことが明らかとなった。

（1）買い取り価格の交涉領域は不確実性により影響を受 ける。

（2）不確実性の度合いは，メリット最大化に基づき決定 できる。

（3）IPPの不確実性は，社会コスト最小化に基づき決定 される一般需要家の供給信頼度を低下させる。

（4）IPPの不確奏性が一般需要の変動上相関索持つ場合、 需要家停電単価の低下により, IPPの参入量が増加 寸る。

ただし、上記の結果（4）は、IPPを含む場合だけでなく、 IPPを含まないこれまでの電力システムに打放電気事業 者側電源の経済性上信頼度の関倸でも、同様な結諭を得る ことができる。しかしながら、一般に、IPPは電気事業者 の直接管理下に六い電源として不確寒性がより大きいもの と考えられるため、需要家停電単洒心影響をより強く受け ることになる。

現在の日本の入札制度における不確実性に対する扱い方 (全てのIPPに対して出力変動辫在数\%以内) は, 制度発 足後間もないということもあり，市る程度政策的に決定さ れている感が否めない。今後は，そ心不確実性が与える様 々な影響老詳細に検討した上で，社会全体にとって適切な ルールづくりを行う必要がある。本論文でり提案手法は, その上うなルールの設計を行う際に, 基礎的ツールとなり うるものと考えている。

な㧍，今回用いたモデルはIPP供給電力の不確実性执上 びその系統負荷との相関の影響を明確にするため，基礎的 なモデルに基づき倹討を行った。今後はさらに，多時間带 モデル人の拡張，およびIPP内自社需要に予測誤差が存在 し，自社需要を抑制させるケースについて検討を加えたい と考えている。

最後に，本研究を行うにあたり終始御指導いただいた本 学大学院工学研究科田中英一助手, ならびに本論文作成 にあたり有益な御助言をいただいた本学大学院工学研究科 博土後期課程三島裕樹氏に深謝申し上げます。

(平成 9 年 6 月 30 日受付、同 9 年11月13日再受付)

$$
\text { 文献 }
$$

(1)矢島正之：「電力市場の自由化と将来展望」電学誌、115巻、 11 号、pp.717-720 (平7)

(2)浅野浩志：「電力自由市場化での需給マネジメントのモデル 化」電学論B、115巻、3号、pp.207-210 (平7)

(3)线野、桑烟：「コジェネレー夕老含む電力供程システムのグ 一么論的解析」電学諭B、113巻、7号、pp.713-719 (平5) 
(4)「特集：新しい電力輸送・供給システム」電学論 B、117巻、 1号、pp.1-67 (平9)

(5)「虎視眡々と電力市場への進出狙う産業界」エネルギーフォ ーラム、11月号、pp.65-69、1993年、電力新報社

(6)「新しい分散型電源の導入技術に関する米国調查報告書」電 気学会燃料電池分散配置技術調查専門委員会他、平成 9 年 4 月

(7)R.Billinton,S.Adzanu : "Adequacy and reliability cost/worth implications of nonutility generation", IEE Proc.-Gener. Transm. Distrib., Vol.143, No.1, Jan., 1996

(8)A.K.David : "Risk modelling in energy contracts between host utility and BOT plant investors", IEEE Trans. on Energy Conversion, Vol.11, No.2, June 1996

(9)鈴木光男：「ゲーム理論入門」共立出版（昭56）

(10)重次、茅：「自家発電を考虑した電力時間帯別料金」電学論 B、114巻、10号、pp. $207-210$ (平 4 )

(11)松川 勇：「負荷遮断料金によるデマンドサイド・マネジメ ント」エネルギー・資源 Vol. 14, No.6, pp.530-535 (平5)

(12)秋澤、浅野、茅：「コジェネ分散型電源の導入比率の分析 一発電効率の与える影響一」電気学会電力技術研究会資料 PE-94-21 (平6).

(13)杉原、北、西谷、長谷川：「電力系統におけるIPPの導入評 価に関する検討」電気学会電力技術研究会資料、PE-96-54 (平8)

付表 1 各種電源コストデータ

App. table 1 Cost data of power source.

\begin{tabular}{r|r|r|c}
\hline & \multicolumn{2}{|c|}{ 電気事業者 } & \multirow{2}{*}{ IPP } \\
\cline { 2 - 3 } & 平常用 & 緊急用 & (自家発) \\
\hline 固定費 $[¥ / \mathrm{kW} \cdot \mathrm{yr}]$ & 40000 & 20000 & 40000 \\
可変費 $[¥ / \mathrm{kWh}]$ & 7 & 14 & 4 \\
\hline
\end{tabular}

付表 2 需要量および設備量データ

App. table 2 Demand and generation capacity of each customers.

\begin{tabular}{c|c|c}
\hline & 一般需要 & 大口需要 \\
\hline 需要 $\mathrm{D}$ 平均値 $[\mathrm{MW}]$ & 2000 & 150 \\
需要D分散 $\left[\mathrm{MW}^{2}\right]$ & $300^{2}$ & $30^{2}$ \\
設備量 $[\mathrm{MW}]$ & $*$ & 300 \\
\hline \multicolumn{2}{|c}{} & $*$ : 計算の結果決定される
\end{tabular}

杉原英治 (学生員) 1972年 8 月29日生。95年 3 月大

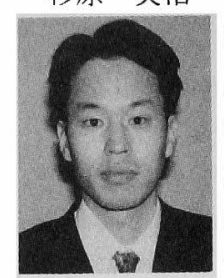
阪付立大学工学部電気工学科卒業。97年 3 月北海道大学大学院工学研究科システム情 報工学専攻修士課程修了。同年 4 月同大学 大学院博士後期課程へ進学、現在に至る。 主として、電カシステムの信頼度評価に関 する研究に従事。日本OR学会会員

北裕幸（正員）1963年 5 月 7 日生。88年 3 月北海

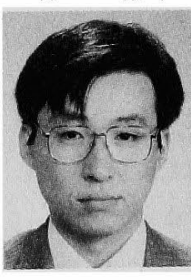
道大学大学院工学研究科電気工学専攻修士 課程修了。89年 4 月同大学工学部電気工学 科助手、95年 4 月同大学大学院工学研究科 システム情報工学専攻助教授となり、現在 に至る。博士（工学）。主として電力系統 の計画・運用・制御に関する研究に従事。 日本OR学会会員。

西谷 健一（正員）1947年 2 月11日生。69年3月北海

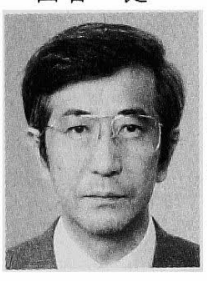
道大学理学部物理学科卒業。同年 4 月同大 学工学部電気工学科助手、同助教授を経て、 91 年 4 月北海道工業大学電気工学科教授、 現在に至る。電力系統工学、特に電力系統 状態推定、解析及び運用・計画に関する研 究に従事。工学博士。シ㳅么制御情報学会会 員。

長谷川 淳（正員）1943年12月13日生。71年3月北海

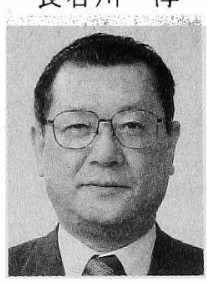
道大学大学院工学研究科電気工学専攻博士 課程修了。同年 4 月同大学工学部講師、同 助教授を経て、85年 4 月同教授。95年 4 月 改組により、同大学大学院工学研究科シス テム情報工学専攻電磁エネルギーシステム 工学講座担当となり、現在に至る。主とし て: 電力系統の計画・運用・制御・解析、 およびエネルギー貯蔵に関する研究に従事。 工学博士。IEEE、日本OR学会、照明学会、 エネルギー・資源学会、低温工学協会会員。 